\title{
A hagyományos kabuki és a shinpa háborúja a 19-20. század fordulóján
}

\begin{abstract}
“Az ősi japán színjátékok előadásain elenyészik az idő. Az ezerháromszáz éves bugaku-táncok 舞楽, a több mint fél évezrede született nó-játék 能, a három és fél évszázada egyfolytában virágzó $k a b u k i$ 歌舞伎 és a végső formáját kétszázötven éve elnyert bunraku 文楽 közönségét egyszerre tartja fogva a jelen és a múlt. Mert eredeti ragyogásukban, az időben változatlanul élnek e hajdan nagy mügonddal kikristályosított színházi formák, s a nézőkre letünt korok hűvös lehelete árad a színpadról. Mégsem vonhatják ki magukat a játék hatása alól, hiszen az a jelen egyidejüségében érvényesül, fölszabadítja az érzelmeket, és fölforrósítja a kedélyeket. "1
\end{abstract}

A Meiji-megújuláshoz ${ }^{2}$ kötődő gyors nyugatiasodás és modernizáció a hagyományos japán színházat is megérintette, de egyik forma sem tudott reagálni a „hirtelen” változásokra. A 14-15. század folyamán kialakult nó már a kabuki 17. századi születésekor is rögzült szabályrendszerrel rendelkezett, s összetettségét, kifinomultságát csak a legmüveltebbek tudták élvezni. Ulysses S. Grant ${ }^{3}$ Japánban tett látogatása után maga mondta, hogy ezt a múfajt meg kell őrizni: „Egy ilyen nemes és gyönyörü müvészet könnyen értéktelenné válhat és lerombolódhat az idő változó ízlése miatt. [Ezért önöknek] erőfeszítéseket kell tenniük a megőrzéséért." ${ }^{4} \mathrm{~S}$ egy, a nyugati hatalmat reprezentáló személytől tett ilyenfajta elismerő kijelentés megerősítette a japánokat abban, hogy a nó az ország jelképe, melynek ezáltal esélye sem volt a változásra.

1 Duró 1984: 89.

2 A Meiji ishin 明治維新 megfelelőjeként Takó (2017) nyomán nem a részben félrevezető, illetve européer konnotációkat idéző „Meiji-restauráció” vagy „Meiji-forradalom” összetételeket, hanem a „Meiji-megújulás” szókapcsolatot használom.

3 Ulysses S. Grant (1822-1885), az Amerikai Egyesült Államok 18. elnöke (hivatali idő: 1869-1877), aki volt elnökként 1879-ben világkörüli útja során Japánban is járt, s itt egy kabuki- és egy nó-elöadáson is részt vett.

4 Keene 1973: 44. 
A megújulást követően a nyugati hatások egyre erősödő tükrében a kabuki szintén egyfajta nosztalgikus érzést váltott ki a virágzó Tokugawa-évek 徳川 után, de ennek a müfajnak a „megmerevedése” ellen jelentős küzdelem indult mind színészi, mind kormányzati oldalról. Ennek vizsgálatához azonban látni kell a kabuki kialakulásának körülményeit, $\mathrm{s}$ kapcsolódását a kor politikai-társadalmi problémáihoz.

\section{Kabuki}

A kabuki szinte egy időben született a Tokugawa-sógunátussal, amely egy több évtizedes polgárháborús időszakot zárt le (Sengoku jidai 戦国時代, Hadakozó fejedelemségek kora), 1467-1600), s hozott jólétet és gazdagságot az országnak. A rend és a béke fenntartása, valamint az új hatalom megszilárdítása azonban nem zajlott zökkenőmentesen. A kabuki szó eredetileg a ma már használaton kívüli kabuku 傾く igéből származik, melynek jelentése „elhajolni”. A kabukuval eredetileg minden olyan „eretnek” dolgot jelöltek, amely valamilyen módon eltért a hagyományostól. A Tokugawa-korszak elején alakultak ki a kabuki-monók 傾奇者 csoportjai, akik kifejezetten az új rend ellen lázadtak. Ezek az általában urukat vesztett szamurájok vagy épp jelentős szamuráj dinasztiák sarjai erőszakos tüntetéseik, merényleteik ${ }^{5}$ mellett extrém viselkedésükkel és megjelenésükkel (eltérő ruházat és hajviselet, túldíszített és hatalmas kardok hordása, négy láb hosszú pipák használata) is felhívták magukra a figyelmet.

A szigorú politikai és társadalmi stabilitás kialakítása hatással volt a színházra is: „,a] közembereknek igen ritkán volt alkalmuk nó-előadást látni, minthogy a nó müvészete a szamurájok kiváltsága volt", 6 így nem csoda, hogy az emberek Kiotóban 京都 elragadtatással fogadták az új múfajt, mely a merev rendszerrel, illetve a nó már évszázados hagyományával szemben jelent meg. A legenda szerint 1603-ban egy Izumóból 出雲 származó, Okuni 阿国

5 1612-ben például egy Tokugawa-hivatalnok kivégeztetett egy kabuki-monót, mire a fiatalember „testvérei” bosszút álltak és merényletet követek el a hivatalnok ellen. De 1607-ben az udvarban is megjelent az irányzat, s férfiak egy csoportja, akik szintén kabuki-monóknak nevezték magukat, nöi ruhába öltözve jutottak be a palota férfiak elől elzárt részébe, és megerőszakolták az ott lévő hölgyeket. A bünösöket ez esetben is kivégezték, a megesett hölgyeket számüzték, vö. Ortolani 1995: 164-165.

6 Nakamura 1992: 23. 
nevü nő - egyes források szerint az izumói Nagy Szentély papnője - dalokból és táncokból állított össze egy előadást, amelyet a Kamo-folyó (Kamogawa 鴨川) kiszáradt medrében mutatott be. Tánca eredetileg nenbutsu-odori 念仏踊り volt, amely egy Amida Buddhát dicső́tő vallási tánc, ám ezt egyfajta „vallási eklektikában” mutatta be, mivel buddhista öltözéke ellenére arany kereszt lógott a nyakában, míg a tánchoz shintō kellékeket használt. Merész és botrányos része volt továbbá előadásának, mikor férfiruhába öltözve vitába keveredett egy női ruhát viselő férfival, vagyis éppen a biológiai nemnek megfelelő szereposztással ellentétesen járt el. ${ }^{7}$ A legenda szerint Okuni kedvese, a szamuráj Nagoya Sanzaemon 名古屋山三重問, aki jártas volt a nó mủvészetében, szintén tanított Okuninak táncokat. ${ }^{8} \mathrm{~S}$ ugyan a közönség hamar megszerette az újdonságot, hamarosan még többet vártak tőle.

Az új műfaj szinte azonnal összekapcsolódott a kabuki かぶき főnévvel, melyhez hozzáillesztették az odori おどり, „tánc” szót, így az új színházi formát eleinte kabuki-odorinak かぶきおどり hívták. S épp e név miatt tekintett gyanakvással rá a hatalom is: „A sógunátus szemében a korai kabuki egy másik fajtája volt a lázadó nonkonformizmusnak, perverzitásnak, transzvesztitizmusnak, felháborító kosztümöknek és a vallási és szabados tartalom hibrid keverékének."

A kabuki név azonban gyorsan formálódott, s pár éven belül megszületett ma is használatban lévő alakja és írásjegyei: $k a$ 歌 (,ének”) $b u$ 舞 (,tánc”) $k i$ 伎 (,,ügyesség”, „készség”). ${ }^{10} \mathrm{~A}$ kabuki tehát már keletkezésekor is egy reakció volt, s nemcsak a nó „elművésziesedésére” és elérhetetlenségére, hanem a kialakuló társadalmi-politikai helyzetre is.

Okuni előadásai hamar népszerüek lettek, és több követőre is találtak, akik szintén művészien kezdték művelni a táncokat. Elmondható, hogy a kabuki bizonyos értelemben olyan színjátéktípus, amelyet az Edo-kor (Edo jidai 江戸時代, 1603-1868) közembere számára, az egyre növekvő városi lakosság szórakoztatása céljából hoztak létre, így a fő célja is a szórakoztatás és a szépség megmutatása volt. Gombamód kezdtek szaporodni az ilyen jellegű színházak, ahol látványos színpadképekkel, jelmezekkel és kellékekkel ejtették ámulatba a szórakozni vágyó közönséget. A béke és stabilitás beálltával rengeteg rōnin 浪人, gazdátlan szamuráj maradt munka nélkül, így

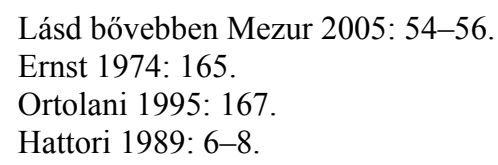


elsősorban ők és a társadalmon kívüli emberek álltak kabuki-színésznek a női előadók mellé. Okuninak és a kabuki-odorinak sok követője akadt, köztük voltak a yunák 湯女, fürdőházi lányok is. A kor fiataljainak, kabuki-monóinak kedvelt szórakozása volt a nyilvános fürdőbe járás, ahol a fürdőházi lányok társaságát élvezve masszázst, mosdatást kaptak, s változatos szórakoztatásban részesültek, többek között kabuki-odoriban is. A yunák azonban nem müvelték ezeket a táncokat olyan kifinomultan, mint Okuni müvészi követői, s a megfelelő hatás érdekében női bájaikat is bevetették, így a produkció egyfajta sztriptízzé alakult. Miután a hatóságok felfigyeltek az új müfaj eme prostituálódására, a sógun 将軍 1629-ben rendeletet adott ki, melyben betiltotta a női, azaz onna-kabukit 女歌舞伎. Letartóztatás vagy büntetés terhe mellett a nőknek ettől fogva tilos volt akár táncosként, akár színészként színpadra lépni, és zenére vagy anélkül mozogni. ${ }^{11}$

Az új fóvárosban, Edóban 江戸 ekkor négy színház létezett - a Yamamura-za 山村座, az Ichimura-za 市村座, a Nakamura-za 中村座 és a Morita-za 森田座 -, melyek az 1629-es rendelet után, hogy működési engedélyüket megtarthassák, kizárólag férfiakkal kezdtek dolgozni. A női szerepeket szép arcú fiatal fiúk vették át, ám a szamurájok fiúk iránti lelkesedése és a homoszexualitás növekedése miatt 1652-ben a fiú, azaz wakashu-kabukit 若衆歌舞伎 is betiltották. A kabuki-színházak erre a lépésre úgy reagáltak, hogy a fiatal fiúk haját elöl leborotválták, ami a felnőtt férfiak hajviseletének számított, s így alakult ki a férfi, vagyis yarō-kabuki 野郎歌舞伎. ${ }^{12} \mathrm{Ez}$ a verzió természetesen eleinte sokkal kevésbé volt vonzó, mint elödei, de a közönség igényeinek érdekében hamar megjelentek az onnagaták 女形, azok a férfi színészek, akik kifejezetten női szerepek eljátszására specializálódtak. Vagyis a kabuki olyan színjátéktípussá alakult, melyben minden szerepet férfiak játszanak, s ez a hagyomány olyan erősnek bizonyult az elmúlt évszázadokban, hogy a mai napig fennáll.

A Meiji-megújulás azonban jelentős változást idézett elö, s lényegében ebben az „időszakban merevedett a kabuki klasszikus színházzá. „Az [...] Edo-korszakba visszanyúló gyökerekkel rendelkező müfaj ekkor vált végérvényesen a múlt termékévé, mivel már nem volt képes kölcsönhatásba kerülni a modern kultúrával." ${ }^{, 13}$ Próbálkozások természetesen voltak, hiszen a három

11 Nakamura 1992: 34.

12 A színházak részéről ez nem kibúvó volt a rendelet alól, ugyanis ha egy fiú férfikorba lépett, törvényileg kötelező volt leborotválni haját, amely a fő szexuális vonzerőt adta.

13 Kokubu 1984: 72. 
meglévő kabuki-típuson kívül - shosagoto 所作事, ${ }^{14}$ jidai-mono 時代物, ${ }^{15}$ sewa-mono 世話物 ${ }^{16}$ - ekkor alakult ki két új típus, a zangiri-mono 散切 り物 ${ }^{17}$ és a katsureki-mono 活歴物. ${ }^{18}$ Maga a kabuki üdvözölte a megújulást, de hamar kiderült, hogy a nyugati kultúra beáramlása a színháznak egy sokkal szélesebb spektrumát mutatta meg a japánoknak, amelyhez a müfaj már nem ért fel. Az újításokkal való próbálkozások ellenére anakronizmussal vádolták, amellett, hogy groteszkül tradicionális, s ez a kormánynak is kényelmetlenséget okozott. 1886-ban a cambridge-i egyetemen frissen diplomázott Suematsu Kenchō 末松謙澄 (1855-1920) megszervezte a Színházreformmozgalmat (Engekikairyō undō 演劇改良運動), melynek célja volt ,a színházi kultúra intézmény[rendszer]be alakítása, amely képes élen járni a társadalmi fejlödés és az intelligencia művelésében". ${ }^{19}$ A kabuki komplett megreformálása továbbá illeszkedett a kormány többi modernizációs programjába is. Fő törekvéseiket három pontban foglalták össze: 1) tanult férfiak által írt, valós történelmi tényeken alapuló drámák színpadra állítása, melyek erősítik a nemzet magabiztosságát; 2) nők alkalmazása a női szerepek eljátszására; 3) az európai stílusú színházvezetés átvétele.

Ezzel együtt a korszak legnagyobb kabuki-színészei, az akkori, vagyis dinasztiájában a IX. Ichikawa Danjūrō 市川團十郎 (1838-1903) és az V. Onoe Kikugorō 尾上菊五郎 (1844-1903), valamint Kawatake Mokuami 河竹默 阿弥 (1816-1893) drámaíró igyekeztek fenntartani a több száz éves hagyományt, melyet örökül hagytak rájuk elődeik, de próbálták a kabukit a magas kultúra részévé is tenni. „Nem elégedtek meg a hagyományos játékformával és stílussal (kata). Meg akarták találni az észszerüséget ezekben, így mindketten

14 „Táncdráma”, mely zenei kíséret és táncfajta szerint is több altípusra osztható.

15 „Történelmi darab”, mely témáját az Edo-kor előtti (aktuális politikai eseményeket tilos volt színpadra állítani) történelmi alakok tetteiből, életéből és a hozzájuk kapcsolódó legendákból meríti.

16 „Jelenkori darab”, mely témáját a közemberek hétköznapi életéből és problémáiból (tiltott szerelem, társadalmi elvárás és egyéni érzelmek konfliktusa stb.) meríti.

17 „Rövid hajviseletes darab”. 1872-től rendelet tiltotta az addig hagyományos férfi hajviseletet (felborotvált homlok és konty), vagyis a nyugati „divatnak” megfelelöen a rövid haj lett a mérvadó. Témáit a Meiji-megújulás utáni új korszak mindennapjaiból meríti.

18 „Élő történelmi darab”. Ebben a típusban, szemben a jidai-monóval, már úgy ábrázolták a történelmi tényeket, ahogy valójában megtörténtek, tehát az előadások szigorúan az igazságon alapultak, és kortárs témával is foglalkozhattak.

19 Katsuya 2014: 218. 
létrehoztak teljesen új formákat, vagy a régieket töltötték meg friss intenzitással és színes megközelítéssel az észszerüség érdekében."20

Erőfeszítéseik azonban nem hozták meg egészében a vágyott eredményt. A kormánynak való feltételen megfelelés érdekében támogatták a nacionalista és agresszív terjeszkedési politikát, ${ }^{21}$ mellyel elérték, hogy Meiji császár 1887-ben megtekintsen egy kabuki előadást Inoue Kaoru 井上馨 külügyminiszter házában. ${ }^{22}$ Ezzel sikerült a kabukit is az államilag elismert elöadóművészetek rangjára emelni. Ebből eredően változás figyelhető meg a színészek iránti tiszteletben is, hiszen a kabuki kialakulásának időszakában társadalmi megítélésük rendkívül alacsony volt. Még megjelenésükben is kötelezően jelezniük kellett foglalkozásukat haj- vagy ruhaviseletükkel, nehogy véletlenül összekeverjék őket a városi lakossággal. Ráadásul egészen a Meiji-korszakig az onna- és a wakashu-kabuki miatt gyakran a prostituáltakkal is összemosták őket. Bár az évszázadok alatt az egyes dinasztiák egyre híresebbek lettek, és tagjaiknak sztároknak megfelelő életkörülmények között teltek napjaik, az igazi társadalmi megbecsülés csupán a császár előtt való fellépéstől datálható. Mára pedig a japán állam a legkiválóbb művészeket „Élő Nemzeti Kincsnek” (Ningen Kokuhō 人間国宝) ${ }^{23}$ tekinti.

Hiába viszont a császári elismerés, ugyanis paradox módon épp ennek volt köszönhető, hogy a müfaj - a reformkísérletek dacára - egyre inkább „megmerevedett", s a nóhoz hasonlóan klasszikus múfajjá vált.

\section{Az új színházi energiák katalizátora - a shinpa}

Az Edo-korban kialakult és virágzó kabukira a Meiji-megújulás jelentős változást hozott. A külföldi kultúra beáramlásával az embereket egyre inkább az új, és föként a nyugati érdekelte, amellyel a 250 év alatt rögzült formákkal dol-

20 Bowers 1974: 204-205

21 Vö. Maruyama 1995: 22.

22 Somogyi 2016: 48.

23 Az „Élő Nemzeti Kincs” népszerü elnevezése a kulturális értékek védelméért hozott törvény által adományozott állami kitüntetésnek, a „Fontos immateriális kulturális értékek őrzője” (Jūyō Mukei Bunkazai Hojisha 重要無形文化財保持者) címnek. A második legnagyobb müvészeti kitüntetés Japánban. 
gozó kabuki kevés sikerrel tudta felvenni a versenyt. Elkerülhetetlen volt, hogy egy modernizációs hullám a színházon is végigsöpörjön.

Az új színházi törekvés eleinte politikai színezetet kapott. Természetesen akadtak olyan emberek, csoportok, akik ellenezték az új kormány mindenre kiterjedő modernizációs törekvéseinek módszereit. Közéjük tartozott a Liberális Párt (Jiyūtō 自由党) is, mely fóként a polgári jogok védelme érdekében szállt síkra. 1884-ben a kormány feloszlatta a pártot, agitáló, kormányellenes gyüléseiket pedig betiltotta, így más utat kellett keresniük, hogy elérjenek a néphez. Kézenfekvő megoldássá vált, hogy nézeteiket nyilvános előadásokon, egyes újságok hasábjain, illetve a színház keretei között jelenítsék meg, s folytassák a kormánnyal szembeni küzdelmet. A liberális mozgalom fiatal vezetói voltak a sōshik 壮士 („bátor fiatal”, vagy „csatlós”), akik népszerü dalok, sōshi-bushik 壮士節 előadásával terjesztették lázadó gondolataikat. A színházban való fellépések és kampányolás ötlete Sudō Sadanoritól 角藤定憲 (1867-1907) származott, aki korábban rendőrként, később újságíróként dolgozott Kiotóban, majd a kialakuló új rendszer láttán csatlakozott a sōshi mozgalomhoz. A halála után ,az új színház atyja” névvel illetett férfi vezetése alatt jött létre 1888-ban egy sōshikból álló csoport, a Nagy Japán Társaság a Színház Reformjáért (Dainippon Geigeki Kyōfūkai 大日本芸劇矯風会), mely a nyugatiasodást támogatta, és e cél terjesztésének érdekében a színházat használta.

\section{Sudō Sadanori}

Sudō úgy vélte, hogy a különböző, színpadon előadott politikai beszédek a gyerekek és idősek számára nehezen érthetők, ráadásul állandóan tartani kellett a müsorok betiltásától, amennyiben a rendőrség túl transzgresszívnek ítélte az elhangzottakat. ${ }^{24}$ Ezért döntött amellett, hogy a színház irányába tesz lépéseket, hiszen egy-egy előadáson keresztül érthetőbben tudta bemutatni a problémákat, melyek foglalkoztatták.

Sudō 1888-ban Oszakában 大阪 tartotta első előadását társulatával a Takashima-zában 高島座, s a politikai dalok mellett felléptek többek között Sudō regénye, $A$ bátor diák (Gōtan no shosei 剛胆の書生) dramatizált változatával Kiotóban és Tokióban is, ahol elsöprő sikereket értek el. Az előadás-

24 Ihara 1933: 649 . 
ban viszont egyfajta közjátékként megjelentek a szónoklatok, így például szó esett az engedélyezett prostitúció eltörléséről is, mely népszerủ szociális reformnak számított a korszakban. ${ }^{25}$

Ennek következtében Sudō a színházi sikerei miatt egyre távolodott a politikától, s társulatával egyre inkább kora társadalmi problémáit kezdte színre vinni. Az 1894 és 1895 között zajló japán-kínai háború tökéletes témát szolgáltatott, így sorra születtek a háborús tematikájú előadások, melyekben a japán katonák hazafiasan és derekasan harcoltak, miközben a közönség legnagyobb csodálatára ágyúk is megjelentek a színpadon. ${ }^{26}$ Ezek az újszerü próbálkozások határozták meg a shinpa 新派, vagyis „új iskola” alapjait. Először az újságok kezdték „új iskolának” nevezni a müfajt, mivel a már klasszikusnak számító kabukitól próbálták ezzel az elnevezéssel megkülönböztetni, de a modernizáló törekvések ellenére összetevői alig különböztek a „régi iskoláétól” (kyūha 旧派). ${ }^{27}$

Sudō társulatán kívül más amatőr, illetve diákcsoportok is elkezdtek foglalkozni az új müfajjal, s a férfi színészek mellett nőket is szerepeltettek, elöször az 1629-es betiltást követően.

A női kabuki-játszás már a Meiji-megújulás előtt is létezett. Az okyōgenshinek お狂言師 nevezett nők kizárólag női közönség előtt, zárt helyeken, például a sógun vagy egy daimyō 大名 rezidenciájának női lakrészében mutatták be előadásaikat. Ezek az alkalmak biztosítottak lehetőséget a női tánctanárok képzésére és a kultúrakedvelő szamuráj- és kereskedőcsaládok hölgytagjainak szórakoztatására. A Meiji-megújulást követően 1877-ig - a nők színpadon való szereplésének betiltását eltörlő törvényig - félhivatalosan müködő női társulatok alakultak az okyōgenshikből, akik a tokiói kereskedelmi színházakban fellépve a másod- és harmadosztályú férfi kabuki versenytársaivá tudtak válni. Ebben az időszakban már onna-yakushaként 女役者, vagyis „női előadókként” emlegették őket, előadásaik pedig onnashibai 女芝居, ,női darabok” vagy musume-kabuki 娘歌舞伎, azaz „lánykabuki” néven futottak. ${ }^{28} \mathrm{~A}$ férfiakat és nőket egyaránt foglalkoztató vegyes

\footnotetext{
Liu 2006: 218-219.

Kokubu 1984: 78.

Ortolani 1995: 233.

28 A müfaj kiemelkedő képviselöje volt Ichikawa Kumehachi 市川久女八 (1846?-1913), aki IX. Ichikawa Danjūrō első női tanítványa. Tehetsége volt a férfi szerepek eljátszásához, és kiválóan imitálta a kortárs kabuki-,,sztárokat” is. 1893-ban saját női társulatot alapított. Bővebben lásd Edelson 2008: 69-98.
} 
társulatok tilalmát azonban csak néhány évvel később, 1891-ben oldották fel, s ezt követően jelentek meg elöször a férfiak mellett nők is a shinpa színpadán. Az úttörő a gésa előélettel rendelkező Chitose Beiha 千歳米坡 (1855-1913) volt, aki 37 évesen, a törvény feloldását követően állt elöször színpadra a Seibikan 済美館 társulat tagjaként az Egy hölgy erkölcsössége: a politikai pártok gyönyörü története (Seitō-bidan shukujo no misao 政党 美談淑女之操) című előadásban. ${ }^{29}$ Ennek ellenére a japán színháztörténetírás mégsem őt, hanem a szintén gésa elóélettel rendelkező Kawakami Sadayakkót 川上貞奴 (1871-1946) tekinti az ország első színésznőjének. ${ }^{30}$

A nők szerepeltetése mellett számos új színházi szokást is bevezettek, többek között a nézőtér elsötétítését, a darabok témáját illetően pedig továbbra is megjelent a társadalmi, politikai színezet az előadásokban. Leggyakrabban különbözö újságok cikkeit és kortárs írók műveit vitték dramatizált formában színre, s a Meiji-korszak ,családi életének romantikusan fölnagyított valóságával foglalkoztak." ${ }^{31}$ Ezáltal sikerült a diákszínházat a hivatalos színjátszás színvonalára emelni, és megmutatni, hogy a hagyományos színházi monopóliumon kívül is lehetőség van a „túlélésre”. ${ }^{32}$ Fontos megjegyezni azonban, hogy a shinpa-színészek játéka valójában szinte alig tért el a hivatásos kabuki-színészekétől, s emellett realisztikusnak sem volt mondható. Sőt, a színésznők helyét - hiába az újitás - rövid idő után ismét átvették az onnagaták, s az előadások fordulópontján vagy csúcspontján előszeretettel alkalmaztak kimerevített pózokat, szintén a kabuki mie pózait idézve. ${ }^{33}$ Valójában azonban ezek az apró eltérések is elkezdték kivezetni a japán színházat a hagyományos kabuki uralma alól. Alapvetően elmondható, hogy a japán színháztörténet csak évtizedekkel később kezd valódi jelentőséget tulajdonítani a shinpának mint olyan müfajnak, amelynek sikerült megtörnie a ,jeget”, és ezzel megnyitnia az utat az új színházi müfajok kialakulásának lehetősége előtt. Az új szokások bevezetésével - elsötétített nézőtér, megtervezett színpadi világítás, nők szerepeltetése a színpadon - „megmutatták a tradicionális színházi monopóliumon kívül való létezés lehetőségét."34

\footnotetext{
29 Rimer - Mori - Poulton 2014: 6.

30 Sadayakkóról lásd bővebben Doma 2013.

31 Kokubu 1984: 78.

32 Ortolani 1995: 235.

33 Kokubu 1984: 79.

34 Ortolani 1995: 234-235.
} 
Sudō - aki élete nagy részét a színháznak szentelte - társulatával mindvégig az ország különböző tartományait járta, de a nagyvárosokban csak szórványos sikereket ért el, mivel nehezen tudta felvenni a versenyt a kabukival és saját reformjának új „utódjával”, a lényegesen jobban szervezett és agresszívebb, Kawakami Otojirō 川上音二郎 (1864-1911) vezette társulattal. ${ }^{35}$

\section{Kawakami Otojirō}

Kawakami Otojirō jelentősége - akárcsak az elödjének nevezhető Sudōé vitathatatlan a japán színháztörténetben, bár sokan csupán úgy tekintenek rá, mint aki szélmalomharcot vívott a sokak által megkövültnek vélt japán színház ellen. Vitathatatlan az is, hogy sosem rendelkezett elméleti vagy esztétikai programmal, de a legtöbben úgy gondolják, Kawakami kezdő lépései nélkül sokkal később jelent volna meg az ,új dráma”, a shingeki 新劇, vagyis ő volt az a személy, aki elültette a modern dráma magjait a szigetországban. ${ }^{36}$ Sudōhoz hasonlóan Kawakami is a rendőrségnél kezdte pályafutását, majd 1883-ban csatlakozott a népszerủ polgárjogi mozgalmak támogatói közé, ö is sōshi lett. Nyilvános tüntetéseket szervezett, és a mozgalom vezetőit is védte. Emellett rendszeresen írt vitaindító írásokat, cikkeket és tiltakozó dalokat, melyeket az utcán adott elő. Számos rendőri atrocitást követően döntött úgy, hogy humorosabb megközelítését próbálja adni a témának, így művei talán a cenzúrán is átmennek. Felvette a Szabadság Kölyök (Jiyū Dōji 自由童子) müvésznevet, s szatirikus dalok és beszédek előadásába fogott, melyekkel hamar hírnevet szerzett magának. ${ }^{37}$

Mivel a sōshi-mozgalom egy ponton elkezdett összefonódni az előadóművészettel, Kawakami 1891-re eljutott odáig, hogy saját előadást hozzon létre. Először a Nakamura-za színpadán lépett fel, s sikerét belépőjének köszönhette: az Oppekepē bushit ${ }^{38}$ オッペケペ節 énekelte, miközben kezében egy japán zászlóval fel-alá szaladt a színpadon. ${ }^{39}$ Előadásához húsz

\footnotetext{
Ortolani 1995: 235

Anderson 2011: xi.

Anderson 2011: 4.

38 A kor legnépszerübb és leghatásosabb dala, mely kritizálta az új társadalom tisztviselöit és az újgazdagokat. A dal refrénje, az „O pe ke pe po pe po pō” pedig az európai katonai trombita hangját imitálta.

39 Ortolani 1995: 236.
} 
amatőr színészt verbuvált, akikkel 1891 februárjában Osaka külvárosában kairyō engeki 改良演劇, vagyis „reformdráma” meghatározással hirdették Az államigazgatás csodálatos története ${ }^{40}$ (Keikokubidan 経国美談) címü előadásukat. Ezt követte nem sokkal később az Itagaki úr szerencsétlenségének igaz története (Itagakikun sōnanjikki いたがきくん遭難実機). ${ }^{41} \mathrm{Az}$ előadások népszerüek voltak, s a társulat több japán nagyvárosban is szerepelt velük. A produkciók ugyan kabuki stílusúak voltak, de Kawakami egyre jobban törekedett rá, hogy lazítson a müfajhoz kötődő szálakon, és valami újabbat, frissebbet mutasson közönségének. ${ }^{42}$

Japán annak érdekében, hogy minél jobban megismerje a nyugati kultúrát, követeket küldött Európába és az Egyesült Államokba is. A szigetország a látogatások eredményei alapján mindenkitől azt próbálta átvenni, amiben a legjobbnak bizonyultak. Így például a britektől a tengerészetet és a vasutat, a franciáktól a hadsereget és a törvényeket, a németektől a kormányzás felépítését és az oktatást, az amerikaiaktól a mezőgazdaságot. A nyugati színházat azonban senki nem tanulmányozta, ezért 1887-ben a legnagyobb elismerésnek örvendő kabuki-színész, IX. Ichikawa Danjūrō szeretett volna külföldre menni - mutatva ezzel a kabuki szándékát is a megújulás iránt - és tapasztalatokat gyüjteni, ám vállalkozása végül kudarcba fulladt. Néhány évvel később Kawakami is arra a meglátásra jutott, hogy külföldi látogatásra van szükség, így támogatóinak köszönhetően 1893 februárjától három hónapot töltött Párizsban, és a legkülönbözőbb előadásokat tekintette meg. ${ }^{43}$

Visszatérve máris újításokat eszközölt színházában: világítási effekteket tett az előadásaiba, arra kérte a színészeket, hogy amikor nevetnek vagy sírnak, valóban próbálják átélni az adott érzelmet, ne csak a formalizált konvenciókat kövessék, illetve szerette volna, hogy a csatajelenetek sokkal valóságosabbak legyenek. Egyértelmű tehát, hogy Kawakami a Párizsban tapasztalt naturalista-realista színjátszás egy-két mozzanatát próbálta kabuki stílusú előadásaiba integrálni. Ezzel megkezdődött a japán színház „,kiegyenesítése”, mely általános értelemben a színház realisztikusabbá válásának elkerülhetet-

40 A történet alapjául az 1883-ban megjelent, Yano Ryūkei 矢野龍溪 által írt népszerű novella szolgált, amelyet pedig Plutarkhosznak a thébai Epameinóndaszról írt története ihletett (Anderson 2011: 16).

41 Az előadás az 1882-es Itagaki Taisuke 板垣退助 (a Liberális Párt alapítója) elleni merényletkísérletet mutatta be. A legenda szerint a földre zuhanó Itagaki a következöket kiabálta: „Itagaki meghalhat, de a szabadság soha!”

42 Anderson 2011: 18.

43 Anderson 2011: 21-22. 
len folyamatát jelöli, vagyis törekvés indult az európai eredetủ logocentrikus színház létrehozására. ${ }^{44}$ Utazásáról való visszatérése után Kawakami egyik ilyen „új típusú” produkciója volt a Meglepetés-sorozat (Igai 意外), amely három, újsághír alapján készült bűnügyi előadást foglalt magába. Újdonságnak számított és vegyes érzelmeket váltott ki a nézőkből az elektromos világítás és a különböző effektek (naplemente, holdfény) alkalmazása a színpadon, valamint a jelenetek közötti teljes elsötétítés, amely - a kabuki-hagyományoktól eltérően - lehetővé tette az ,észrevétlen” díszletváltozást (a $k a$ bukiban épp a nyíltszíni bravúros változást értékelték). Emellett a harci jelenetekbe dzsúdó-mozdulatokat épített, a hagyományos shamisen-zenét 三味線 pedig európaival helyettesítette. ${ }^{45}$

A valódi áttörést és sikereket azonban az 1894-1895-ben zajló japánkínai háború ihlette darabjai hozták meg. A valósághüségre való törekvés miatt ezek a darabok sokkal népszerübbek voltak, mint a kabuki színészek által színre vitt hasonló témájú előadások, és jó példái az „egyenesedésnek”. A háború kitörését követően tévé és film híján rengeteg társulat vitte színre az eseményeket, s 1894-ben a Kawakami-társulat is bejelentette következö produkciójának készülését:

„Azzal a céllal, hogy növeljük nemzetünk dicsfényét és bátorítsuk csapataink harci szellemét, megrendezzük a japán-kínai háborút egy látványos előadásban. Igyekszünk, hogy a közönség úgy érezze, ott van a csata sürüjében, és saját szemével láthassa, ahogyan a vitéz tábornokok és a bátor katonák úgy harcolnak, mint a sárkányok, és úgy küzdenek, mint a tigrisek. Alázattal kérünk minden hazafit, hogy hozzák magukkal az országunk iránti hüség igaz érzését, jöjjenek és nézzék meg ezt a nagy és lenyűgöző látványosságot." ${ }^{\text {46 }}$

Mint a fenti idézetből is kitünik, az előadás egyik célja az volt, hogy a közönség úgy érezze, egy a harcoló férfiak közül. A Japán-kínai háború (Nisshin sensō 日清戦争) című előadás - mely két japán újságíró történetét mutatta be a háború alatt ${ }^{47}$ - Jules Verne Michel Strogoff (Sztrogoff Mihály)

44 Vö. Kano 2001: 58.

45 Anderson 2011: 22.

46 Kano 2001: 62.

47 A két japán újságíró belekeveredik az egyik ütközetbe, majd kínai fogságba esnek, és a börtönben kínzásnak vetik alá őket. Egyikük nem éli túl a megpróbáltatásokat, míg másikukat a kínai hadsereg parancsnoka, Li tábornok elé viszik. Itt a bátor japán új- 
címü müvének és Adolphe D’Ennery La Prise de Pékin (Peking elfoglalása) című drámájának elegyítése. ${ }^{48}$ Az előadásban több női karakter is megjelent (vöröskeresztes japán nők és egy kínai lány, aki valójában álruhás japán), de mindegyik szerepet - jelezve a női színjátszás „,nehézkes” alkalmazásának voltát - férfiak játszották. A kabukitól eltérően azonban a férfi karakterek már nem használtak sminket, hanem saját arcukat mutatták a közönségek. A történet pedig - a női szereplők megléte ellenére - egyáltalán nem tartalmazott romantikus szálat, a mü egyértelmüen csupán a japán katonák hősiességét és a nemzet egységét mutatta be a közönségnek. A színpadon Japán - mely a háborúval az ország modernizációs és nagyhatalmi törekvéseit kívánta elősegíteni - úgy jelent meg, mint a civilizált Nyugat, szemben a lemaradt Kínával, a Kelettel. Míg a kínai katonák szalmából készült sisakot és lófarkat viseltek, addig a japán katonák nyugati uniformisban és Ferenc József-szakállal masíroztak, s mindegyikük bátor és hősies volt, szemben a könnyen megvesztegethetö, ügyetlenül harcoló és kegyetlen kínai katonákkal. ${ }^{49} \mathrm{Az}$ üzenet már-már didaktikusan világos volt: ha japán vagy, akkor csak tisztességes ember lehetsz, és mind egységben harcolunk civilizált nemzetünkért. Amellett, hogy az előadás akarva-akaratlanul a háborús propaganda „gyöngyszemévé” vált, népszerüségét elsősorban a csaták realisztikus bemutatásának köszönhette, $\mathrm{s}$ a korabeli beszámolók alapján a nézők valóban úgy érezték, hogy ott vannak a harcmezőn. Többek között valódi ágyúkat vontattak a színpadra, petárdákkal imitálva elsütésüket, valamint valódi ökölharc folyt a kínai és a japán katonák között. Utóbbi olyannyira felkavarta a közönséget, hogy egy alkalommal két néző a helyét elhagyva rátámadt a kínai harcosokat megtestesítő színészekre. ${ }^{50}$

A Japán-kinai háborút követően Kawakami új darabját - hogy még hitelesebbé tegye - személyes tapasztalatokra kívánta építeni, így Koreába utazott a frontvonalhoz, s ebből az élményből született a Kawakami Otojirō frontnaplója (Kawakami Otojirō senchi kenbun nikki 川上音二郎戦地見聞日記) című előadás. Míg első háborús előadásában egy fiktív riportert alakított, itt saját magát és valódi élményeit vitte színpadra. A darab olyannyira népsze-

ságíró szónoklatot intéz a tábornokhoz, melyben kifejti Ázsia és Kína jelenlegi politikai helyzetét, s legitimálja Japán hadba lépését. Az előadás Peking elfoglalásával és a győztes japán csapatok „Banzai 万歳” örömkiáltásaival ér véget (vö. Kano 2001: 63).

48 Liu 2006: 116.

49 Liu 2006: 119-120, Kano 2001: 64-65.

50 Vö. Kano 2001: 65-66. 
rüvé vált, hogy a társulat lehetőséget kapott, hogy a legjelentősebb kabukiszínpadon, a tokiói Kabuki-zában 歌舞伎座 mutassa be előadását, így megtörtént az addig elképzelhetetlen: a shinpa Kawakami vezetésével ezen a ponton „legyőzte" a kabukit. ${ }^{51}$

A kortárs színháztörténészek véleménye egyezik abban, hogy Kawakaminak nem a müvészi értékek képviselete, hanem a szenzációkeltés volt az erőssége, s elsősorban ennek köszönhető, hogy a 19. század végére Japán ünnepelt színészévé és „,színházcsinálójává” vált, olyan rendezővé, aki mind a darabválasztás, mind a színrevitel során a hagyományos kabuki-színháztól eltérő müfaj kialakítására törekedett. Az 1900-as évek elején - több éves nyugati turnéjáról való hazaérkezése után - e törekvések jegyében nevezte újabb és újabb előadásait seigekinek 正劇, ${ }^{52}$ vagyis , egyenes színháznak/drámának”, s nyitotta meg színházát, a Birodalmi Színházat (Teikoku-za 帝国座) Osakában, mely a kor „legeurópaibb” színházának számított Japánban.

\section{A shinpa ,pirruszi győzelme"}

A Sudō- és a Kawakami-féle társulatok mellett más színházi csoportok is gombamód szaporodtak az 1800-as évek végén. Ezek igyekeztek javítani az előadások és a játékmodor minőségén is. Ilyen jelentős csoport volt többek között a már említett Seibikan, a Seibidan 成美団, az Isami-engeki 伊佐水 演劇 és a Hongō-za 本郷座. A Seibikan-csoportból - mely lényegében egy előadást hozott létre 1891-ben - indult a kor egyik kiemelkedően híres shinpaművésze, Ii Yōhō 伊井蓉峰 (1871-1932), aki később az Isami-engeki alapítói között volt. A Seibidan-társulatot Takada Minoru 高田実 (1871-1916) alapította 1896-ban, miután kivált Kawakami Otojirō társulatából. A csoport

51 Ortolani 1995: 236.

52 Azt, hogy Kawakami gondolkodása milyen szorosan kötődik a kelet-ázsiai tradicionális gondolkodásmódokhoz, jól tükrözi a sei 正 írásjegy (illetve terminus, kínai zheng) használata, melynek az ,igaz”, „helyes”, „,egyenes” jelentéseket lehet tulajdonítani, de ezen felül világos jelentéssel bír a konfuciánus értékeken nevelkedett japánok számára. Az írásjegyet ugyanis Kínában tipikusan a konfuciánus értékrendhez kapcsolódva használják hosszú évezredek óta mint bevett kifejezést valamilyen eredetileg jól müködő, ám később eltorzult dolog helyreállítására. Ezáltal a mindenképpen újító szándékú tanítás, esetleg reform, nem tesz mást, mint helyrehozza az adott dolgot, esetünkben kiegyenesíti az „elhajló” színházat, a kabukit. 
lényegében két év elteltével eltünt a színházi palettáról, de Takada továbbra is folytatta színházi munkásságát, és a realisztikus játéktechnikát tanította diákjainak, ezzel elősegítve a shinpa professzionalizálódását. Az Isami-engekit a kor legnépszerübb előadói alapították: Ii Yōhō, Satō Toshizō 佐藤俊三 (1869-1945) és Mizuno Yoshimi 水野好美 (1869-1945), akik családnevük első írásjegyeiből alkották a híres társulat nevét. Jelentőségük abban állt, hogy - az elismert kortárs japán írók müveinek színpadra állítása mellett újrainterpretálták a régi japán legendákat és mondákat is, életben tartva az ősi japán hagyományt, mégis közeledve a nyugati, modern áramlatokhoz. ${ }^{53}$

1903-ban a két kiemelkedően jelentős kabuki „titán”, IX. Danjūrō és V. Kikugorō halálával vákuum keletkezett a tokiói színházi életben, ami a japánorosz háború kitörésével együtt jelentős mértékben hozzájárult a shinpa felemelkedéséhez. Ez az esemény megfelelő témát nyújtott a folyamatosan

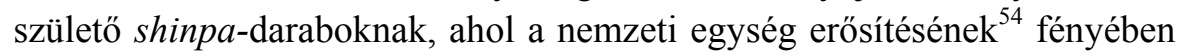
hős japán katonák adták életüket a hazáért a közönség legnagyobb örömére. Több tucat hasonló témájú előadás született, sőt olyan próbálkozások is voltak, melyek keretében a shinpa-színészek kabuki-müvészeket hívtak meg előadásaikba. Megkeresésüket azonban visszautasítás fogadta, s az együttmüködés helyett a kabuki-színészek maguk hoztak létre sensōgeki 戦争劇 vagy gunjigeki 軍事劇, vagyis háborús, illetve katonai témájú előadásokat. Ezek egyik almüfaja volt az ichiyazuke 一夜漬け, „egyéjszakás savanyúság” előadás, mely nevével is arra utalt, hogy a darab rekordsebességgel - gyakran a reteksavanyításhoz elegendő egy éjszaka alatt - készült, s a shinpához hasonlóan az aktuális harci eseményekre, a katonák hősies megmozdulásaira (bidan 美談) kívánt reagálni, ám kevesebb sikerrel, mint az „új iskola” realisztikusabb előadásai. ${ }^{55}$ A kabukiban az új almüfaj kialakulása is mutatja, hogy a shinpa elérte aranykorát, és rendkívül nagy befolyással bírt a tokiói színházi világban, s lassan megtörtént, ami néhány éve még elképzelhetetlen volt: átvette a vezetést a professzionális színházban. ${ }^{56}$ Sikerét már nemcsak az újszerü drámáknak, háborús daraboknak, kortárs írók müveinek vagy a napi

53 Ortolani 1995: 238-239.

54 A II. világháború alatt a kabuki fontos részét képezte az állami propagandának, számos, a katonák hőstetteit dicső́tő darab, bidan 美談 született, melyek mind igazolni kívánták az ország katonai lépéseit és megnyerni a társadalom támogatását. Bővebben lásd Somogyi 2016: 43-79.

55 Brandon 2009: 4.

56 Vö. Sullivan 2015. 
aktualitások dramatizálásának köszönhette, hanem a játékmodor rohamos javulásának is. Köszönhetően a számos társulatnak és a kialakult versenyhelyzetnek, az amatőr színészeket felváltották a képzettek, azok az írók pedig, akiknek a müveit színpadra alkalmazták, elkezdtek kimondottan shinpa-drámákat írni, elösegítve ezzel a klasszikus shinpa-repertoár kialakulását. 1907-ben 230 shinpa-színész közremüködésével megalakult az Új Színészek Nagykoalíciója (Shinhaiyū Daidō Danketsu 新俳優大道団結), mely ugyan csak két hónapig müködött, de létezésének ténye szintén megmutatta a shinpa egyre növekvő erejét. ${ }^{57}$

Az aranykort azonban néhány év múlva hanyatlás követte. Az „új színházi energiák katalizátoraként" müködő shinpa nem tudott tovább fejlődni, s a modern, nyugati stílusú új drámával, a shingekivel képtelen volt felvenni a versenyt. Az 1911-ben megalakult Társulás az Új Korszak Színházáért (Shinjidaigeki Kyōkai 新時代劇協会) és az 1913-ban létrejött Nyilvános Színház Társulat (Kōshū Gekidan 公衆劇団) is próbálkozott eszközöket találni az érdeklődés fenntartására, de kevés sikerrel, s a Meijit követő Taishōkorszakot 大正時代 (1912-1926) nagyon nehezen élte túl a múfaj. Az 1930-as évekre lassan elfoglalta végső helyét a tokiói színházi életben, s Inoue Masao 井上正夫 (1881-1950) 1937-es definíciójával élve chūkan-engeki 中間演劇, vagyis ,köztes színház” lett, átmeneti müfaj a tradicionális kabuki és a modern shingeki között. A II. világháború hozott még egy utolsó fellendülést, ismét müködni kezdtek új és addig „,vegetáló” társulatok, s újra előkerültek a szeretett háborús, patrióta előadások. A háború után azonban ismét krízisbe került a shinpa ${ }^{58}$ Mára viszont már klasszikussá vált, $\mathrm{s}$ a színháztörténészek szemében szinonimája lett a Meiji-kori szentimentális, könnyed, régivágású drámáknak és előadásoknak, amely valahol a hagyományos kabuki és a realista shingeki között helyezkedik el.

$\mathrm{S}$ bár a japán színháztörténetben kiemelt szerepe volt Sudō Sadanorinak és Kawakami Otojirōnak is, mint a shinpa valódi alapítóinak, alkotóinak, jelentőségük a II. világháborút követően gyakran háttérbe szorul a kabuki és a shingeki művészeié mellett. Ez egyrészt annak köszönhető, hogy bizonyos kereteken túl már ez a múfaj sem tudott újat hozni, másrészt teljes mértékben hozzákapcsolódott a „köztes színház” megjelölés, amely determinálta további létezését. Véleményem szerint azonban nem szabad megfeledkezni arról, hogy

57 Ortolani 1995: 239-240.

58 Ortolani 1995: 240-241. 
a shinpa nélkül nincs shingeki, vagyis - a sokak által átmenetinek tekintett jellege ellenére - megkerülhetetlen müfaj volt, mely lehetővé tette a modern színház megjelenését Japánban.

\section{Másodlagos szakirodalom}

Anderson, Joseph L. 2011. Enter a Samurai: Kawakami Otojiro and Japanese Theatre in the West. Tucson: Wheatmark.

Bowers, Fabion 1974. Japanese Theatre. Rutland, Vermont \& Tokyo: Charles E. Tuttle Company.

Brandon, James R. 2009. Kabuki's forgotten war 1931-1945. Honolulu: University of Hawai'i Press.

Doma Petra 2013. „Az Idegen vonzásában: Sadayakko és Matsui Sumako színészi (ön)definíciója a nyugati és a japán színházmüvészetben.” Theatron. 12/4: 74-91.

Duró Győző 1984. „Színház az örökkévalóságnak.” In: Kokubu Tamocu: A japán színház. Budapest: Gondolat, 89-125.

Edelson, Loren 2008. „The Female Danjūrō: Revisiting the Acting Career of Ichikawa Kumehachi." The Journal of Japanese Studies 2008/1: 69-98.

Ernst, Earle 1974. The Kabuki Theatre. Honolulu: University of Hawaii Press.

Hattori Yukio 服部幸雄 1989. Kabuki no keewaado 歌舞伎のキーワード [Kabuki kulcsszavak]. Tokyo: Iwanamishinsho.

Ihara Toshirō 伊原敏郎 1933. Meiji engekishi 明治演劇史 [Meiji színháztörténet]. Tokyo: Waseda Daigaku Shuppanbu.

Katsuya Hirano 2014. The Politics of Dialogic Imagination: Power and Popular Culture in Early and Modern Japan. Chicago: The University of Chicago Press.

Keene, Donald 1973. Nō-The Classical Theatre of Japan. Tokyo: Kodansha.

Kokubu Tamocu 1984. A japán színház. Budapest: Gondolat.

Liu, Siyuan 2006. The Impact of Japanese Shinpa on Early Chinese Huaju. (PhD dissz., University of Pittsburgh, online elérhetőség: http://d-scholarship.pitt.edu/9876/1/ SiyuanLiuDiss2006.pdf, utoljára megtekintve: 2017.07.25.)

Maruyama Masao 丸山眞男 1995. „Chōkokkashugi no ronri to shinri 「超国家主義 の論理と心理」 [Az ultranacionalizmus logikája és lélektana].” In: Maruyama Masao shū 丸山眞男集 3. Tōkyō: Iwanami, 17-36.

Mezur, Katherine 2005. Beautiful Boys / Outlaw Bodies: Devising Kabuki Female-Likeness. New York: Palgrave MacMillan.

Nakamura Matazó 1992. Kabuki-Az öltözöben és a színpadon. Budapest: Gondolat.

Ortolani, Benito 2005. The Japanese Theatre: From Shamanistic Ritual to Contemporary Pluralism. Princeton, N.J.: Princeton University Press.

Rimer, J. Thomas - Mori Mitsuya - Poulton, M. Cody 2014. The Columbia Anthology of Modern Japanese Drama. New York: Columbia University Press. 
Somogyi Viktória 2016. „A kabuki mint a háborús propaganda eszköze a huszadik század első felében.” In: Birtalan Ágnes - Csáki Nelli - Takó Ferenc (szerk.) Keleti kutatások. Budapest: ELTE BTK Távol-keleti Intézet, 43-79.

Sullivan, Michael 2015. „Shinpa Theatre - Investigating Japanese Theatrical Forms.” Japanstore.jp. 2015. június 9. http://japanstore.jp/blog/shinpa-theatre-investigatingjapanese-theatrical-forms/ [Utoljára megtekintve: 2017.03.09]

Takó Ferenc 2017 [2018]. „Fordítva. Nyugati társadalomfilozófiai koncepciók és termi nusok »japanizációja« a korai Meiji érában.” Távol-keleti Tanulmányok 2017/2: $151-187$. 